\title{
Optimisation of the Enzymatic Hydrolysis of Blood Cells with a Neutral Protease
}

\author{
Yanbin Zheng, Qiushi Chen, Anshan Shan, and Hao Zhang \\ Laboratory of Biotechnology, Institute of Animal Nutrition, Northeast Agricultural University, Harbin 150030, China \\ Correspondence should be addressed to Anshan Shan; asshan@neau.edu.cn
}

Received 27 August 2012; Revised 17 October 2012; Accepted 21 October 2012

Academic Editor: Elvira Gonzalez De Mejia

Copyright (C) 2013 Yanbin Zheng et al. This is an open access article distributed under the Creative Commons Attribution License, which permits unrestricted use, distribution, and reproduction in any medium, provided the original work is properly cited.

For utilizing the blood cells (BCs) effectively, enzymatic hydrolysis was applied to produce the enzymatically hydrolyzed blood cells (EHBCs) by using a neutral protease as a catalyst. The results of the single-factor experiments showed optimal substrate concentration, enzyme to substrate ratio $(\mathrm{E} / \mathrm{S}), \mathrm{pH}$, temperature, and incubation period were $1.00 \%, 0.10,7.00,50.00^{\circ} \mathrm{C}$, and $12.00 \mathrm{~h}$, respectively. The optimized hydrolysis conditions from response surface methodology (RSM) were pH 6.50, E/S 0.11, temperature $45.00^{\circ} \mathrm{C}$, and incubation period $12.00 \mathrm{~h}$. Under these conditions (substrate concentration $1.00 \%$ ), the degree of hydrolysis $(\mathrm{DH})$ was $35.06 \%$. The free amino acids (FAAs) content of the EHBCs (35.24\%) was 40.46 times higher than BCs while the total amino acids (TAAs) content was lower than BCs. The scores of lysine (human 0.87; pig 0.97), valine (human 1.42; pig 1.38), leucine (human 1.50; pig 1.90), tyrosine (human 0.84; pig 1.09), and histidine (human 2.17; pig 2.50) indicated that the EHBCs basically fulfilled the adult human and pig nutritional requirements. The calculated protein efficiency ratios (C-PERs) of the EHBCs were 3.94, 6.19, 21.73, and 2.04. In summary, the EHBCs were produced successfully with optimized conditions and could be a novel protein source for humans and pigs.

\section{Introduction}

Blood is a major byproduct of abattoirs in the meat industry with large volumes [1]. It is a potentially low-cost protein source and its recycling would reduce the oxygen burden created by the biodegradation of the pollution from slaughterhouse waters [2]. The protein content of red blood cells (or blood cells) of the whole blood is 34-38\% [1]. The blood cells (BCs), which are obtained by removing the plasma from whole blood, mainly contain the hemoglobin and ferrous in the form of heme-Fe with high bioavailability [3, 4]. The spray-dried blood cells are high in protein and have a favorable AA profile [5]. So, the BCs are widely used in food for animals and humans $[6,7]$. However, the dark redbrown color and the metallic flavor of $\mathrm{Hb}$ are not desirable when it is added to some products [8]. Moreover, the BCs are difficult to be digested (due to the poor utilization of the membrane) and composed of imbalanced amino acids (high content in lysine but short of isoleucine and methionine) for animals and humans. To circumvent these problems, various attempts (e.g., enzymatic hydrolysis) have been made to shear the $\mathrm{BC}$ membrane and improve the functional properties of the protein isolated from the BCs [9]. Enzymatic hydrolysis could eliminate the principal color of BCs by enzymatically hydrolyzing hemoglobin [10]. The protein (nitrogen) recovery was typically $70-80 \%[11,12]$ or more than $80 \%[13]$. The digestibility of the enzymatically hydrolyzed proteins, which replete with FAAs and peptides of various molecular weights, is improved [13,14], and the product is easily absorbed [15].

The blood is frequently contaminated by contact with microorganisms and air-borne bacteria due to the application of the open systems in many industrial abattoirs but not closed collection systems [16]. So some hygienic precautions must be taken for safety during collection to prevent spoilage organisms or even pathogens from growing [16]. Moreover, the spray-drying and the high hydrostatic pressure are used to decrease the total counts of hemolyzed $\mathrm{BC}$ by logarithmic units [17]. The blood from animals that pass both ante- and postmortem inspections can be processed as products for animal and human [18].

The single-factor-at-a-time method is an experimental method that studies the phenomenon of interest by varying 
TABLE 1: The levels of the factors used to optimize the degree of hydrolysis.

\begin{tabular}{lcccc}
\hline Code & $\mathrm{pH}\left(X_{1}\right)$ & Temperature $\left(X_{2},{ }^{\circ} \mathrm{C}\right)$ & $\mathrm{E} / \mathrm{S}\left(X_{3}\right)$ & Incubation period $\left(X_{4}, \mathrm{~h}\right)$ \\
\hline-2 & 6.00 & 40.00 & 0.06 & 6.00 \\
-1 & 6.50 & 45.00 & 0.08 & 8.00 \\
0 & 7.00 & 50.00 & 0.10 & 10.00 \\
1 & 7.50 & 55.00 & 0.11 & 12.00 \\
2 & 8.00 & 60.00 & 0.13 & 14.00 \\
\hline
\end{tabular}

one factor while fixing all other conditions. However, it is necessary to account for the influence of each factor on other factors and consider the interaction between these factors [19]. To address this problem, response surface methodology (RSM) has been proposed to determine the influences of individual factors on each other. As reported recently, statistical experimental design has been applied to optimize conditions used in many areas such as bioenergy, food, and pharmaceutical research [20-22].

The purpose of the present study was to optimize the enzymatic hydrolysis of BCs from porcine blood using a neutral protease. A central composite design (CCD; four factors and five levels) of RSM was employed to study the effects of substrate concentration, $\mathrm{pH}$, temperature, E/S, and incubation period on the $\mathrm{DH}$ of the BCs.

\section{Materials and Methods}

2.1. Substrate and Enzyme. The BCs (ADDY Technology, Inc., Beijing, China) obtained from porcine blood by coagulation and drying. The neutral protease (EC 3.4.24, from Bacillus subtilis) purchased from Amresco is a metalloproteinase that hydrolyzes peptide bonds over a wide $\mathrm{pH}$ range (between 5.5 and 8.5 ) and exhibits maximum activity at temperatures between 45 and $50^{\circ} \mathrm{C}$.

2.2. Proteolytic Activity of the Enzyme. Protease activity was determined by a modification of the Casein-Pholine method [23]. One unit of protease activity was defined as the amount of enzyme that liberated $1 \mu \mathrm{g}$ of tyrosine per min at $50^{\circ} \mathrm{C}$.

2.3. Enzymatic Hydrolysis. Prior to enzymatic treatment, a suspension of BCs was prepared by adding $9.90 \mathrm{~mL}$ of $0.02 \mathrm{~mol} / \mathrm{L}$ buffer to $0.10 \mathrm{~g}$ of flour in a $20 \mathrm{~mL}$ glass hydrolysis tube and maintaining a constant $\mathrm{pH}$ value with an electrochemistry meter (Sartorius, Germany). The suspension was preheated to a constant temperature by placing the tubes in a water bath, and the enzyme was added. The enzymatic hydrolysis was conducted at a constant temperature and $\mathrm{pH}$ value for several hours. The tube was incubated in boiling water for $15 \mathrm{~min}$ to inactivate the enzyme. Then, the mixture in the tub was removed by filtration using filter paper. The filtrate was diluted to $100 \mathrm{~mL}$ with distilled water to determine the $\mathrm{DH}$.

2.4. Degree of Hydrolysis. The degree of hydrolysis was expressed as the ratio of released amino nitrogen after the hydrolysis of the protein to the amount of total amino nitrogen:

$$
\mathrm{DH}(\%)=\frac{h}{h_{\mathrm{tot}}} \times 100,
$$

where $h$ (hydrolysis equivalents) is the amount of peptide bonds cleaved during hydrolysis, which is expressed ad millimole equivalents per gram of protein ( $\mathrm{mmol} / \mathrm{g}$ of protein); $h_{\text {tot }}$ is the total amount of peptide bonds in the protein substrate, which can be determined from the amino acid composition and is $8.62 \mathrm{mmol} / \mathrm{g}$ for BCs.

Amino nitrogen was determined by a modified ninhydrin colorimetric method $[13,24]$. A standard curve graph was generated using $2-20 \mu \mathrm{g} / \mathrm{mL}$ hydrolyzate of the spay-dried blood cell. The procedures used to prepare hydrolyzate of the spay-dried blood cell were as follows. Fifty milligrams of spray-dried blood cells were hydrolyzed at $110^{\circ} \mathrm{C}$ for $24 \mathrm{~h}$ with hydrochloric acid $(6 \mathrm{~mol} / \mathrm{L})$. The hydrolyzate was filtered and diluted to $100 \mathrm{~mL}$ with deionized water. One milliliter of the dilution was freeze-dried and then dissolved in deionized water at $20 \mu \mathrm{g} / \mathrm{mL}$. A standard curve graph was generated using $2-20 \mu \mathrm{g} / \mathrm{mL}$ hydrolyzate. The absorbance at $570 \mathrm{~nm}$ was then measured against the assay components treated with deionized water as a blank. The concentration of the samples' amino nitrogen was determined according to the standard graph curve.

2.5. Experimental Design of RSM. Based on a single-factor experiments for $\mathrm{DH}$, the proper preliminary ranges of the substrate concentration, enzyme-to-substrate ratio (E/S), $\mathrm{pH}$, temperature and incubation period were determined. A fivelevel, four-variable CCD (Design-Expert v. 8.0.6, Stat-Ease, Inc., Minneapolis, MN, USA) was applied to determine the best combination of hydrolysis variables to maximize the $\mathrm{DH}$ of the BCs. Based on the single-factor experiments, the variables considered in this experimental design were the $\mathrm{pH}$, temperature, $\mathrm{E} / \mathrm{S}$ and incubation period. The initial conditions were $\mathrm{pH} 7.00$, temperature $50.00^{\circ} \mathrm{C}, \mathrm{E} / \mathrm{S} 0.01$, incubation period $10.00 \mathrm{~h}$ (the substrate concentration fixed at $1.00 \%$ ). Table 1 lists the CCD matrix and the response values that were used to develop the model. The response value in each trial was an average of triplicates.

2.6. Amino Acid Analysis. The free amino acid (FAA) contents were determined using an L-8900 high-speed amino acid analyzer (Hitachi, Japan) according to Kim et al. [25] with modification. Before the analysis, $5 \mathrm{~mL}$ of the hydrolyzates was added to $5 \mathrm{~mL}$ of $10 \%$ TCA. The sample was 
incubated at the room temperature for $2 \mathrm{~h}$ and centrifuged at $10000 \mathrm{rpm}$ for $15 \mathrm{~min}$. The supernatant collected was filtered with Millipore $0.22 \mu \mathrm{m}$ syringe filters (Milford, MA, USA). The filtrate was loaded onto the amino acid analyzer. The total amino acid (TAA) profiles of the EHBCs were determined according to AOAC [26].

The amounts of the different amino acids were expressed in $\mathrm{mg} 100 \mathrm{mg}^{-1}$ protein and compared with the FAO/WHO [27] and NRC [28] reference patterns. The score of essential amino acids (EAAs) was calculated as shown below:

$$
\text { EAA score }=\frac{\mathrm{mg} \text { of EAA in } 100 \mathrm{mg} \text { of test protein }}{\mathrm{mg} \text { of EAA in } \mathscr{A}},
$$

where $\mathscr{A}$ denotes $100 \mathrm{mg}$ of recommendation protein.

2.7. Calculated Protein Efficiency Ratio. The C-PERs were calculated using the procedures suggested by Alsmeyer et al. [29] and Lee et al. [30]. The procedures were based on the in vitro protein digestibility and the EAA composition of the analyzed sample. The C-PER is one of the most important scores in the evaluation of the nutritional value of proteins. It measures protein quality by feeding a diet comprising $10 \%$ of the test protein to rats and measuring their weight gain, which is an expensive and time-consuming method [31]. This method has also been applied by some researchers to predict the nutritional value of some protein hydrolyzates $[21,31,32]$.

2.8. Statistical Analysis. The data obtained from the CCD design were fitted with a second-order polynomial equation. The equation was as follows:

$$
Y=\beta_{0}+\sum_{i=1}^{2} \beta_{i} X_{i}+\sum_{i=1}^{2} \beta_{i i} X_{i}^{2}+\sum_{i=1} \sum_{j=i+1} \beta_{i j} X_{i} X_{j}
$$

where $Y$ is the predicted response, $\beta_{0}$ is a constant, $\beta_{i}$ is the linear coefficient, $\beta_{i i}$ is the quadratic coefficient, $\beta_{i j}$ is the interaction coefficient, and $X_{i}$ and $X_{j}$ are independent variables. Data were expressed as the mean \pm standard deviation (SD). The statistical significance of the model, model variables was determined at the probability $(P)$ of $0.001,0.01$, or 0.05 .

\section{Results and Discussion}

3.1. Effects of Substrate Concentration on the DH of BCs. As shown in Figure 1(a) (fixed levels: E/S 0.12, $\mathrm{pH} 7.00$, temperature $50.00^{\circ} \mathrm{C}$, and incubation period $6.00 \mathrm{~h}$ ), the substrate concentration $(2.00 \%-16.00 \%)$ and the DH trended in opposite directions, that is, as the substrate concentration increased, the $\mathrm{DH}$ decreased according to the quadratic curve $\left(y=0.24 x^{2}-5.89 x+49.61, R^{2}=0.90\right)$. This trend may be due to the endproduct feedback inhibition caused by hydrolysis yield $[33,34]$. Taking the $\mathrm{DH}$ into account, the optimal substrate concentration was $1.00 \%$, which is similar to that observed by Pérez-Gálvez et al. [9].
3.2. Effects of the E/S on the DH of BCs. As shown in Figure 1(b) (fixed levels: substrate concentration 1.00\%, $\mathrm{pH} 7.00$, temperature $50.00^{\circ} \mathrm{C}$, and incubation period $6.00 \mathrm{~h}$ ), the E/S (0.05-0.16; enzyme activity $124000 \mathrm{U} / \mathrm{g}$ ) and $\mathrm{DH}$ varied with a similar trend. Because the cost of the enzyme contributes significantly to the total cost of the biomass conversion process [35], the E/S should be minimized as much as possible. Many reports $[21,36]$ noted that an increased enzyme concentration reduces the rate of hydrolysis even though the $\mathrm{DH}$ is increased. Considering both the cost and the $\mathrm{DH}$, the optimal E/S was 0.10 .

3.3. Effects of $p H$ on the DH of BCs. The phosphate buffer solutions $(0.02 \mathrm{~mol} / \mathrm{L} ; 5.00<\mathrm{pH} \leq 8.00)$ and glycine-sodium hydroxide buffer solutions $(0.02 \mathrm{~mol} / \mathrm{L} ; 8.00<\mathrm{pH} \leq 9.00)$ were prepared at various $\mathrm{pH}(5.50-9.00)$ values. The $\mathrm{DH}$ by the enzyme decreased below and above the optimum $\mathrm{pH}$ range in a similar manner to the results observed by $\mathrm{Hu}$ et al. [37]. As shown in Figure 1(c) (fixed levels: substrate concentration $1.00 \%, \mathrm{E} / \mathrm{S} 0.10$, temperature $50.00^{\circ} \mathrm{C}$, and incubation period $6.00 \mathrm{~h}$ ), the enzyme exhibited an optimum $\mathrm{DH}$ in the $\mathrm{pH}$ range $5.50-9.00$ with the maximum $\mathrm{DH}$ at $\mathrm{pH}$ 7.00.

3.4. Effects of Temperature on the DH of BCs. As shown in Figure 1(d) (fixed levels: substrate concentration 1.00\%, E/S $0.10, \mathrm{pH} 7.00$, and incubation period $6.00 \mathrm{~h}$ ), the optimum hydrolysis of the BCs by the neutral protease occurred at $50.00^{\circ} \mathrm{C}$. Below $50.00^{\circ} \mathrm{C}$, the increased velocity of the reaction could be explained by the theory of the Arrhenius activation energy [38]. The activation energy was the key reason for the increased enzymatic reaction velocity. The $\mathrm{DH}$ of the protease decreased when the temperature rose above $50.00^{\circ} \mathrm{C}$ because of the thermal denaturation that occurs.

3.5. Effects of the Incubation Period on the DH of BCs. As shown in Figure 1(e) (fixed level: substrate concentration $1.00 \%, \mathrm{E} / \mathrm{S} 0.10, \mathrm{pH} 7.00$, and temperature $50.00^{\circ} \mathrm{C}$ ), as the incubation period increases $(2.00-16.00 \mathrm{~h})$, the $\mathrm{DH}$ increased and the hydrolyzing velocity decreased. In contrast, the investigators $[32,39,40]$ had reported a decrease in the $\mathrm{DH}$ with prolonged incubation periods. Guerard et al. [39] proposed the reduced $\mathrm{DH}$ observed with a prolonged incubation period might be caused by limited enzyme activity by the formation of reaction products at a high $\mathrm{DH}$, the decreased concentration of peptide bonds available for hydrolysis, enzyme inhibition, and enzyme deactivation. Considering the cost, the optimal incubation period was $10.00 \mathrm{~h}$.

\subsection{Optimisation of the Hydrolysis Parameters for $\mathrm{DH}$}

3.6.1. Predictive Model of Response. The influence of $X_{1}$, $X_{2}, X_{3}$, and $X_{4}$ on the hydrolysis by the neutral protease was determined using the factorial design described in the previous section. The best explanatory model equation for 


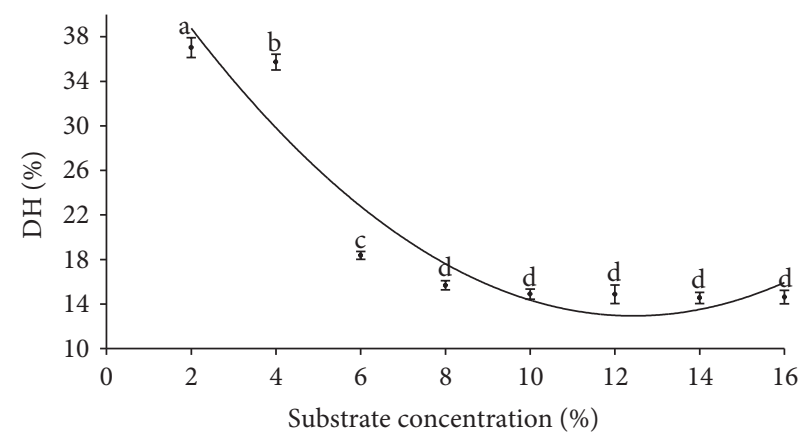

(a)

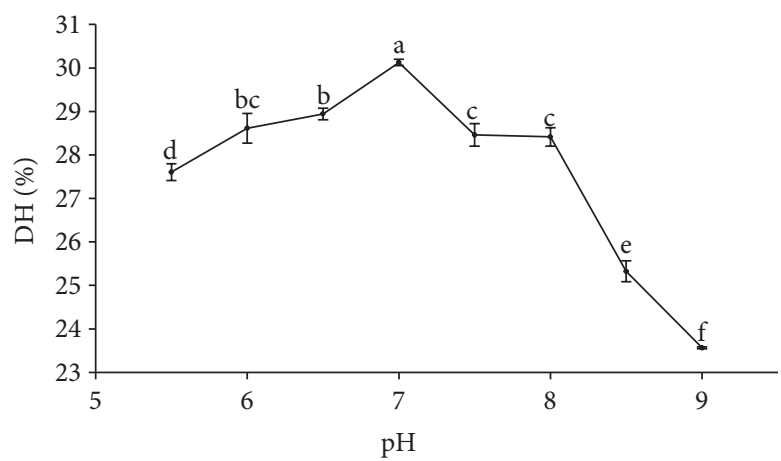

(c)

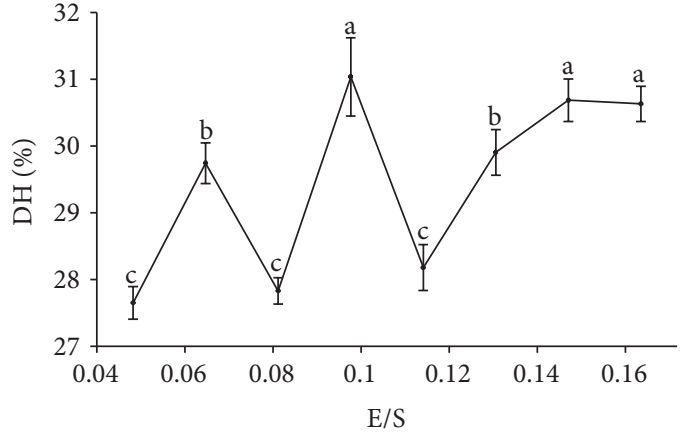

(b)

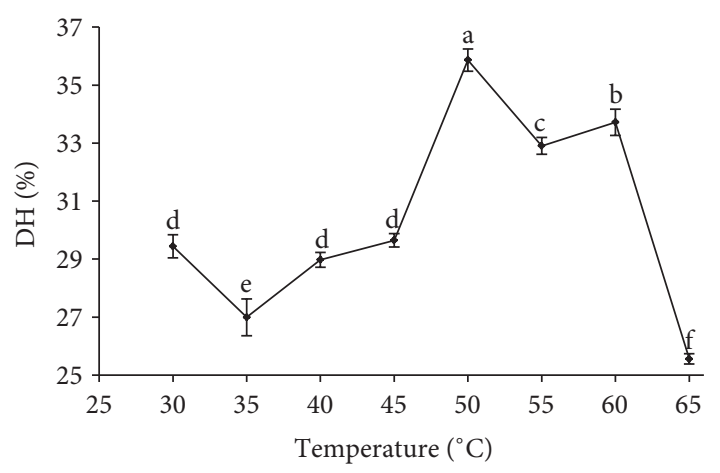

(d)



(e)

Figure 1: The effects of substrate concentration (a), E/S (b), pH (c), temperature (d), and incubation period (e) on the DH.

the $\mathrm{DH}$ value obtained from the neutral protease hydrolysis uncoded data is described in (4):

$$
\begin{aligned}
\mathrm{DH}= & 149.34-17.63 * \mathrm{pH}-2.25 \\
& * \text { Temperature }+811.68 * \frac{E}{S}-8.88 \\
& * \text { Time }+0.06 * \mathrm{pH} * \text { Temperature }-45.74 \\
& * \mathrm{pH} * \frac{E}{S}+0.26 * \mathrm{pH} * \text { Time }-2.69 \\
& * \text { Temperature } * \frac{E}{S}+0.03 * \text { Temperature }
\end{aligned}
$$

$$
\begin{aligned}
& * \text { Time }+20.88 * \frac{E}{S} * \text { Time }+1.19 * \mathrm{pH} \\
& * \mathrm{pH}+0.01 * \text { Temperature } * \text { Temperature } \\
& -2483.73 * \frac{E}{S} * \frac{E}{S}+0.22 * \text { Time } * \text { Time }
\end{aligned}
$$

The experimental values and predicted values for the $\mathrm{DH}$ under various combinations of the independent variables are presented in Table 3. The results indicated that the $\mathrm{DH}$ ranged from $23.26 \%$ to $35.07 \%$, depending on the experimental conditions (Table 2). 
TABLE 2: The degree of hydrolysis at various $\mathrm{pH}$ values, temperatures, E/S values, and incubation periods.

\begin{tabular}{|c|c|c|c|c|c|c|c|c|c|c|}
\hline \multirow{2}{*}{ Run } & \multicolumn{4}{|c|}{ Code values } & \multicolumn{4}{|c|}{ Real values } & \multicolumn{2}{|c|}{$\mathrm{DH}^{*}$} \\
\hline & $X_{1}$ & $X_{2}$ & $X_{3}$ & $X_{4}$ & $X_{1}{ }^{\mathrm{a}}$ & $X_{2}{ }^{\mathrm{b}}$ & $X_{3}{ }^{\mathrm{c}}$ & $X_{4}{ }^{\mathrm{d}}$ & Experimental & Predicted \\
\hline 1 & 0 & 0 & 0 & 0 & 7.00 & 50.00 & 0.10 & 10.00 & $30.26 \pm 0.11$ & 28.60 \\
\hline 2 & -1 & -1 & 1 & -1 & 6.50 & 45.00 & 0.11 & 8.00 & $30.53 \pm 0.51$ & 30.97 \\
\hline 3 & -1 & 1 & 1 & -1 & 6.50 & 55.00 & 0.11 & 8.00 & $27.20 \pm 0.38$ & 26.25 \\
\hline 4 & -1 & 1 & 1 & 1 & 6.50 & 55.00 & 0.11 & 12.00 & $32.32 \pm 0.68$ & 31.73 \\
\hline 5 & 1 & 1 & -1 & -1 & 7.50 & 55.00 & 0.08 & 8.00 & $25.62 \pm 0.56$ & 25.49 \\
\hline 6 & 0 & 0 & 0 & 2 & 7.00 & 50.00 & 0.10 & 14.00 & $35.38 \pm 0.28$ & 36.10 \\
\hline 7 & 2 & 0 & 0 & 0 & 8.00 & 50.00 & 0.10 & 10.00 & $30.21 \pm 0.52$ & 30.21 \\
\hline 8 & 1 & -1 & 1 & 1 & 7.50 & 45.00 & 0.11 & 12.00 & $35.62 \pm 0.70$ & 35.01 \\
\hline 9 & -1 & -1 & -1 & 1 & 6.50 & 45.00 & 0.08 & 12.00 & $30.05 \pm 0.93$ & 29.85 \\
\hline 10 & 0 & 0 & 0 & 0 & 7.00 & 50.00 & 0.10 & 10.00 & $27.49 \pm 0.66$ & 28.60 \\
\hline 11 & 1 & 1 & 1 & 1 & 7.50 & 55.00 & 0.11 & 12.00 & $32.03 \pm 0.09$ & 32.24 \\
\hline 12 & 1 & -1 & -1 & -1 & 7.50 & 45.00 & 0.08 & 8.00 & $28.25 \pm 0.91$ & 28.71 \\
\hline 13 & 0 & 0 & 0 & 0 & 7.00 & 50.00 & 0.10 & 10.00 & $29.70 \pm 0.34$ & 28.60 \\
\hline 14 & 0 & 0 & 0 & 0 & 7.00 & 50.00 & 0.10 & 10.00 & $27.90 \pm 0.71$ & 28.60 \\
\hline 15 & 0 & 0 & 0 & 0 & 7.00 & 50.00 & 0.10 & 10.00 & $28.97 \pm 0.63$ & 28.60 \\
\hline 16 & 0 & 0 & -2 & 0 & 7.00 & 50.00 & 0.06 & 10.00 & $23.26 \pm 0.95$ & 23.25 \\
\hline 17 & -1 & 1 & -1 & 1 & 6.50 & 55.00 & 0.08 & 12.00 & $27.52 \pm 0.45$ & 27.32 \\
\hline 18 & 0 & 0 & 2 & 0 & 7.00 & 50.00 & 0.13 & 10.00 & $27.93 \pm 0.67$ & 28.77 \\
\hline 19 & 1 & 1 & -1 & 1 & 7.50 & 55.00 & 0.08 & 12.00 & $29.88 \pm 0.93$ & 29.31 \\
\hline 20 & 0 & 2 & 0 & 0 & 7.00 & 60.00 & 0.10 & 10.00 & $26.26 \pm 0.39$ & 26.69 \\
\hline 21 & -1 & -1 & 1 & 1 & 6.50 & 45.00 & 0.11 & 12.00 & $35.70 \pm 0.14$ & 35.13 \\
\hline 22 & -1 & -1 & -1 & -1 & 6.50 & 45.00 & 0.08 & 8.00 & $29.30 \pm 0.49$ & 28.39 \\
\hline 23 & 1 & -1 & -1 & 1 & 7.50 & 45.00 & 0.08 & 12.00 & $30.96 \pm 0.70$ & 31.21 \\
\hline 24 & 0 & 0 & 0 & 0 & 7.00 & 50.00 & 0.10 & 10.00 & $27.28 \pm 0.31$ & 28.60 \\
\hline 25 & 1 & 1 & 1 & -1 & 7.50 & 55.00 & 0.11 & 8.00 & $25.67 \pm 0.18$ & 25.73 \\
\hline 26 & 0 & -2 & 0 & 0 & 7.00 & 40.00 & 0.10 & 10.00 & $32.92 \pm 0.09$ & 33.31 \\
\hline 27 & 1 & -1 & 1 & -1 & 7.50 & 45.00 & 0.11 & 8.00 & $30.31 \pm 0.68$ & 29.82 \\
\hline 28 & -2 & 0 & 0 & 0 & 6.00 & 50.00 & 0.10 & 10.00 & $28.55 \pm 0.39$ & 29.38 \\
\hline 29 & 0 & 0 & 0 & -2 & 7.00 & 50.00 & 0.10 & 6.00 & $28.03 \pm 0.33$ & 28.13 \\
\hline 30 & -1 & 1 & -1 & -1 & 6.50 & 55.00 & 0.08 & 8.00 & $24.06 \pm 0.43$ & 24.54 \\
\hline
\end{tabular}

${ }^{*} \mathrm{DH}$ represents the average degree of hydrolysis of triplicate experiments. The DH was calculated using the equation $Y=0.69 A_{570}-0.01\left(R^{2}=0.98\right)$ derived from the standard curve of completely hydrolyzed BCs (absorbance at $570 \mathrm{~nm}$ versus the concentration of the hydrolyzate).

${ }^{\mathrm{a}} \mathrm{X}_{1}: \mathrm{pH}$.

${ }^{\mathrm{b}} X_{2}$ : temperature.

${ }^{\mathrm{c}} X_{3}: \mathrm{E} / \mathrm{S}$.

${ }^{\mathrm{d}} X_{4}$ : incubation period.

Statistical testing of the model was performed by ANOVA, which is required to test the significance and adequacy of the model. The $P$ value for the lack of fit was not significant $(P>0.05)$, thereby confirming the validity of the model. The model was found adequate to predict within the range of the experimental variables. The coefficient values of (4) were calculated and tested for their significance using Design-Expert software and were listed in Table 3. Each $P$ value is used as a tool to check the significance of each coefficient, which in turn may indicate the pattern of the interactions between the variables. It could be seen from this table that the linear coefficients $\left(X_{2}, X_{3}, X_{4}\right)$ and the quadratic term coefficient $\left(X_{4}\right)$ were significant with $P$ values at the 0.001 level, the quadratic term coefficient $\left(X_{3}\right)$ was significant with a $P$ value at the 0.001 level, and the crossproduct coefficients $\left(X_{3} * X_{4}\right)$ were significant with a $P$ value at the 0.05 level. The other term coefficients $\left(X_{1}, X_{1} * X_{2}\right.$, $X_{1} * X_{3}, X_{1} * X_{4}, X_{2} * X_{3}, X_{2} * X_{4}, X_{1} * X_{1}, X_{2} * X_{2}$ ) were not significant $(P>0.05)$. The cleavage of the protein substrate's peptide bonds was markedly influenced by the hydrolysis conditions when the substrate was hydrolyzed with bacterial proteases $[9,21,22,38]$.

The adjusted determination coefficient $\left(R_{\text {Adj }}^{2}\right)$ was used as the correlation measure to test the goodness of fit of the regression equation. The value of $R_{\mathrm{Adj}}^{2}(0.90)$ for (4) was reasonably close to 1 and indicates a high degree of correlation between the experimental and predicted values. Good correlations of experimental results with those 
TABLE 3: ANOVA for the response surface quadratic polynomial model.

\begin{tabular}{|c|c|c|c|c|c|c|}
\hline Source & Sum of squares & $\mathrm{df}$ & Mean square & $F$ value & $P$ value & Significance \\
\hline Model & 0.03 & 14 & $1.88 E-03$ & 20.16 & $<0.00$ & $* *^{\mathrm{a}}$ \\
\hline$X_{1}-\mathrm{pH}$ & $1.04 E-04$ & 1 & $1.04 E-04$ & 1.11 & 0.39 & \\
\hline$X_{2}$-temperature & $6.58 E-03$ & 1 & $6.58 E-03$ & 70.40 & $<0.00$ & ** \\
\hline$X_{3}-\mathrm{E} / \mathrm{S}$ & $4.56 E-03$ & 1 & $4.56 E-03$ & 48.84 & $<0.00$ & $* *$ \\
\hline$X_{4}$-incubation period & $9.53 E-03$ & 1 & $9.53 E-03$ & 102.04 & $<0.00$ & $* *$ \\
\hline$X_{1} X_{2}$ & $4.00 E-05$ & 1 & $4.00 E-05$ & 0.43 & 0.52 & \\
\hline$X_{1} X_{3}$ & $2.18 E-04$ & 1 & $2.18 E-04$ & 2.34 & 0.15 & \\
\hline$X_{1} X_{4}$ & $1.08 E-04$ & 1 & $1.08 E-04$ & 1.15 & 0.30 & \\
\hline$X_{2} X_{3}$ & $7.53 E-05$ & 1 & $7.53 E-05$ & 0.81 & 0.38 & \\
\hline$X_{2} X_{4}$ & $1.74 E-04$ & 1 & $1.74 E-04$ & 1.86 & 0.19 & \\
\hline$X_{3} X_{4}$ & $7.28 E-04$ & 1 & $7.28 E-04$ & 7.79 & 0.01 & $* * * *^{\mathrm{c}}$ \\
\hline$X_{1}^{2}$ & $2.44 E-04$ & 1 & $2.44 E-04$ & 2.62 & 0.13 & \\
\hline$X_{2}^{2}$ & $3.38 E-04$ & 1 & $3.38 E-04$ & 3.62 & 0.08 & \\
\hline$X_{3}^{2}$ & $1.15 E-03$ & 1 & $1.15 E-03$ & 12.32 & 0.00 & $* * *^{\mathrm{b}}$ \\
\hline$X_{4}^{2}$ & $2.12 E-03$ & 1 & $2.12 E-03$ & 22.72 & 0.00 & $* *$ \\
\hline Residual & $1.40 E-03$ & 15 & $9.34 E-05$ & & & \\
\hline Lack of fit & $6.45 E-04$ & 10 & $6.45 E-05$ & 0.43 & 0.88 & \\
\hline Pure error & $7.57 E-04$ & 5 & $1.51 E-04$ & & & \\
\hline Cor. total & 0.03 & 29 & & & & \\
\hline Std. Dev. & $9.67 E-03$ & & & $R$-squared & 0.95 & \\
\hline Mean & 0.29 & & & Adj. $R$-squared & 0.90 & \\
\hline C.V.\% & 3.30 & & & Pred. $R$-squared & 0.83 & \\
\hline PRESS & $4.80 E-03$ & & & Adeq. precisior & 18.81 & \\
\hline
\end{tabular}

df: degree of freedom.

${ }^{\mathrm{a}}$ Significance at 0.001 level.

${ }^{\mathrm{b}}$ Significance at 0.01 level.

${ }^{\mathrm{c}}$ Significance at 0.05 level



FIGURE 2: The relationship between the actual and predicted values of the $\mathrm{DH}$.

predicted by RSM models of proteolytic reactions had been reported by several researchers $[9,20]$. The very low value of the coefficient of variation (C.V.) (3.30\%) clearly indicated the very high degree of precision and reliability of the experimental values.

Figure 2 showed the comparison between the actual values of the $\mathrm{DH}$ with the predicted values of the $\mathrm{DH}$. The plot (Figure 2) demonstrated an acceptable level of agreement.
Moreover, the coefficient $\left(R^{2}=0.95\right)$ showed that the model was a satisfactory mathematical description of the hydrolysis process.

3.6.2. Response Surface Plot and Contour Plot Showing the Effects of the Hydrolysis Variables on the DH of BCs. The graphical representations of the regression (4), known as the response surfaces and the contour plots, were presented in Figure 3. The contour plot in Figure 3(a), which presents the $\mathrm{DH}$ of $\mathrm{BCs}$ as a function of $\mathrm{pH}$ and temperature at fixed $\mathrm{E} / \mathrm{S}$ (0.10) and incubation period $(10.00 \mathrm{~h})$, showed that the $\mathrm{DH}$ of the BCs did not vary as the $\mathrm{pH}$ varies from 6.50 to 7.50 and that the $\mathrm{DH}$ decreased as the temperature increases from 45.00 to $55.00^{\circ} \mathrm{C}$.

From Figure 3(b), it could be seen that the maximum DH of the BCs could be achieved when the $\mathrm{pH}$ and $\mathrm{E} / \mathrm{S}$ are 6.50 and 0.11 , respectively.

From Figure 3(c), it could be seen that DH did not vary as the $\mathrm{pH}$ increases from 6.50 to 7.50 ; the $\mathrm{DH}$ increased steeply as the incubation period increased from 8.00 to $12.00 \mathrm{~h}$.

From Figure 3(d), it could be seen that the DH decreased as the temperature increased from 45.00 to $55.00^{\circ} \mathrm{C}$; the $\mathrm{DH}$ increased as the E/S increased from 0.08 to 0.11 .

From Figure 3(e), it could be seen that the DH decreased as the temperature increased from 45.00 to $55.00^{\circ} \mathrm{C}$, while 
TABLE 4: Free amino acid and total amino acid composition of BCs and EHBCs (g/100 g) and the EAA score compared with the FAO/WHO reference protein.

\begin{tabular}{|c|c|c|c|c|c|c|}
\hline \multirow[b]{2}{*}{ Amino Acids } & \multicolumn{2}{|c|}{ Free amino acid } & \multicolumn{2}{|c|}{ Total amino acid } & & \\
\hline & $\mathrm{BCs}$ & EHBCs & $\mathrm{BCs}$ & EHBCs & & \\
\hline Lysine & - & $4.26 \pm 0.05$ & $8.16 \pm 0.10$ & $5.07 \pm 0.08$ & & \\
\hline Methionine & $0.19 \pm 0.00$ & $1.09 \pm 0.06$ & $0.77 \pm 0.05$ & $0.49 \pm 0.02$ & & \\
\hline Threonine & $0.03 \pm 0.00$ & $1.28 \pm 0.06$ & $3.00 \pm 0.05$ & $1.92 \pm 0.02$ & & \\
\hline Arginine & - & $3.08 \pm 0.04$ & $4.21 \pm 0.11$ & $2.79 \pm 0.06$ & & \\
\hline Histidine & - & $2.84 \pm 0.05$ & $7.21 \pm 0.09$ & $4.12 \pm 0.06$ & & \\
\hline Isoleucine & - & - & $0.19 \pm 0.01$ & $0.21 \pm 0.01$ & & \\
\hline Leucine & - & $6.52 \pm 0.05$ & $15.49 \pm 0.20$ & $9.90 \pm 0.08$ & & \\
\hline Phenylalanine & $0.06 \pm 0.00$ & $4.48 \pm 0.04$ & $6.68 \pm 0.17$ & $4.46 \pm 0.06$ & & \\
\hline Valine & - & $1.38 \pm 0.06$ & $7.45 \pm 0.25$ & $4.97 \pm 0.05$ & & \\
\hline Tryptophan & - & - & - & - & & \\
\hline Serine & $0.03 \pm 0.00$ & $0.56 \pm 0.03$ & $4.30 \pm 0.12$ & $2.33 \pm 0.07$ & & \\
\hline Glutamic acid & $0.08 \pm 0.00$ & $1.36 \pm 0.04$ & $8.06 \pm 0.10$ & $6.03 \pm 0.05$ & & \\
\hline Glycine & $0.33 \pm 0.01$ & $1.42 \pm 0.04$ & $4.52 \pm 0.10$ & $3.25 \pm 0.05$ & & \\
\hline Proline & - & $1.18 \pm 0.03$ & $3.17 \pm 0.09$ & $2.27 \pm 0.07$ & & \\
\hline Cystine & $0.11 \pm 0.00$ & $0.25 \pm 0.01$ & $0.31 \pm 0.03$ & $0.15 \pm 0.01$ & & \\
\hline Aspartic acid & $0.02 \pm 0.00$ & $1.34 \pm 0.02$ & $11.32 \pm 0.54$ & $7.81 \pm 0.09$ & & \\
\hline Alanine & - & $2.99 \pm 0.04$ & $7.73 \pm 0.08$ & $5.46 \pm 0.06$ & & \\
\hline Tyrosine & - & $1.21 \pm 0.01$ & $1.35 \pm 0.05$ & $0.85 \pm 0.05$ & & \\
\hline Total & $0.85 \pm 0.02$ & $35.24 \pm 0.13$ & $93.91 \pm 0.06$ & $62.08 \pm 0.05$ & & \\
\hline \multirow{3}{*}{ Amino acid } & \multicolumn{4}{|c|}{ EAA Score } & \multirow{2}{*}{\multicolumn{2}{|c|}{$\mathrm{RP} 2^{\mathrm{d}}$}} \\
\hline & Reference protein $1^{\mathrm{a}}$ & Reference protein $2^{\mathrm{b}}$ & & & & \\
\hline & & & $\mathrm{BCs}$ & EHBCs & BCs & EHBCs \\
\hline Lysine & 5.80 & 5.25 & $1.41 \pm 0.02$ & $0.87 \pm 0.02$ & $1.55 \pm 0.02$ & $0.97 \pm 0.02$ \\
\hline Threonine & 3.40 & 3.90 & $0.88 \pm 0.02$ & $0.56 \pm 0.01$ & $0.77 \pm 0.01$ & $0.49 \pm 0.01$ \\
\hline Valine & 3.50 & 3.60 & $2.13 \pm 0.07$ & $1.42 \pm 0.01$ & $2.07 \pm 0.07$ & $1.38 \pm 0.01$ \\
\hline Isoleucine & 2.80 & 2.90 & $0.07 \pm 0.00$ & $0.08 \pm 0.01$ & $0.07 \pm 0.01$ & $0.07 \pm 0.01$ \\
\hline Leucine & 6.60 & 5.20 & $2.35 \pm 0.03$ & $1.50 \pm 0.01$ & $2.98 \pm 0.04$ & $1.90 \pm 0.02$ \\
\hline Phenylalanine and tyrosine & 6.30 & 4.85 & $1.27 \pm 0.04$ & $0.84 \pm 0.00$ & $1.66 \pm 0.05$ & $1.09 \pm 0.01$ \\
\hline Tryptophan & 1.10 & 0.95 & - & - & - & - \\
\hline Methionine and cystine & 2.50 & 3.00 & $0.43 \pm 0.03$ & $0.26 \pm 0.02$ & $0.36 \pm 0.03$ & $0.21 \pm 0.01$ \\
\hline Histidine & 1.90 & 1.65 & $3.79 \pm 0.05$ & $2.17 \pm 0.03$ & $4.37 \pm 0.05$ & $2.50 \pm 0.04$ \\
\hline Arginine & - & 2.10 & - & - & $2.00 \pm 0.06$ & $1.33 \pm 0.03$ \\
\hline
\end{tabular}

the $\mathrm{DH}$ increased as the incubation period increased from 8.00 to $12.00 \mathrm{~h}$. From Figure 3(f), it could be seen that the $\mathrm{DH}$ increased as the E/S increases from 0.08 to 0.11 ; the $\mathrm{DH}$ increased as the incubation period increased from 8.00 to $12.00 \mathrm{~h}$. From Figure 3, it could be concluded that the optimal conditions for the hydrolysis of BCs with the neutral protease were $\mathrm{pH} 6.50, \mathrm{E} / \mathrm{S} 0.11$, temperature $45.00^{\circ} \mathrm{C}$, and incubation period $12.00 \mathrm{~h}$. The maximum $\mathrm{DH}(35.13 \%)$ was obtained under the optimal conditions.

To ensure that the predicted result was not biased toward the practical value, experimental rechecking was performed using this deduced condition. A mean value (35.06 $\pm 0.06 \%$; $n=3$ ) was obtained in real experiments validated the RSM model. The good correlation between the model and these results confirmed that the response model was adequate to predict the optimisation.

3.7. Amino Acid Composition. The free amino acid and total amino acid composition of EHBCs $(n=3)$ and the chemical scores were presented in Table 4 . The amino acids were grouped as basic (Lys, His, and Arg), acidic (Asp, Glu, and Asn), charged (basic and acidic amino acids), hydrophilic (charged amino acids, Thr, and Ser), hydrophobic (Val, Leu, Ile, Phe, Tyr, Trp, and Met), and apolar (hydrophobic amino acids except Tyr) [41]. In addition, taste attributes, as described by Tseng et al. [42], were also considered 




- Design points

(a) Fixed levels: $\mathrm{E} / \mathrm{S}=0.10$, Incubation period $=10.00 \mathrm{~h}$

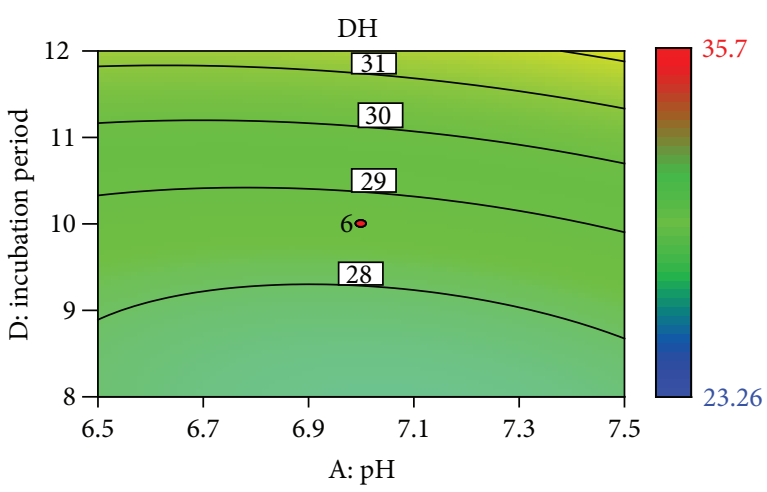

- Design points

(c) Fixed levels: Temperature $=50.00^{\circ} \mathrm{C}, \mathrm{E} / \mathrm{S}=0.10$

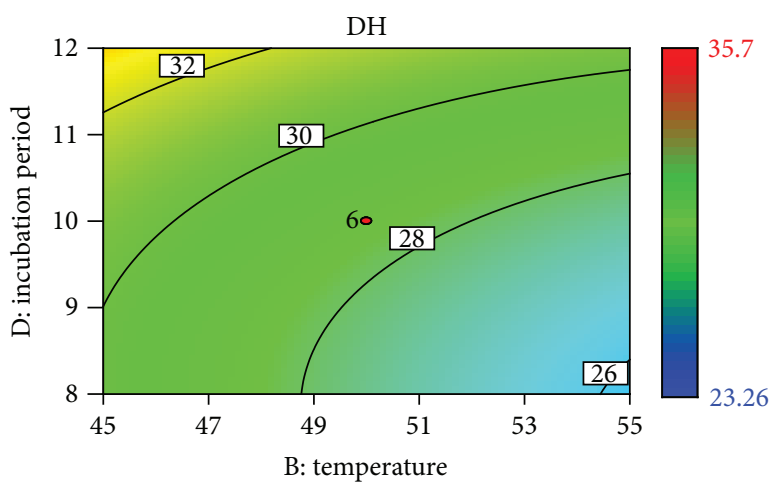

- Design points

(e) Fixed levels: $\mathrm{pH}=7.00, \mathrm{E} / \mathrm{S}=0.10$

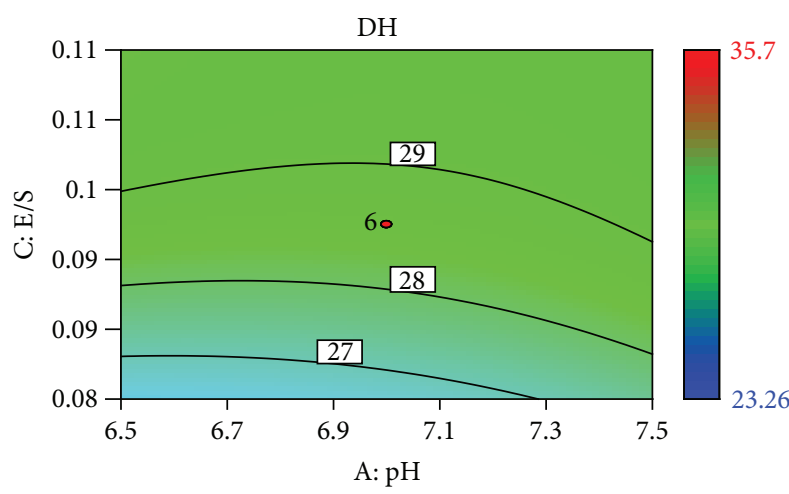

- Design points

(b) Fixed levels: Temperature $=50.00^{\circ} \mathrm{C}$, Incubation period $=10.00 \mathrm{~h}$

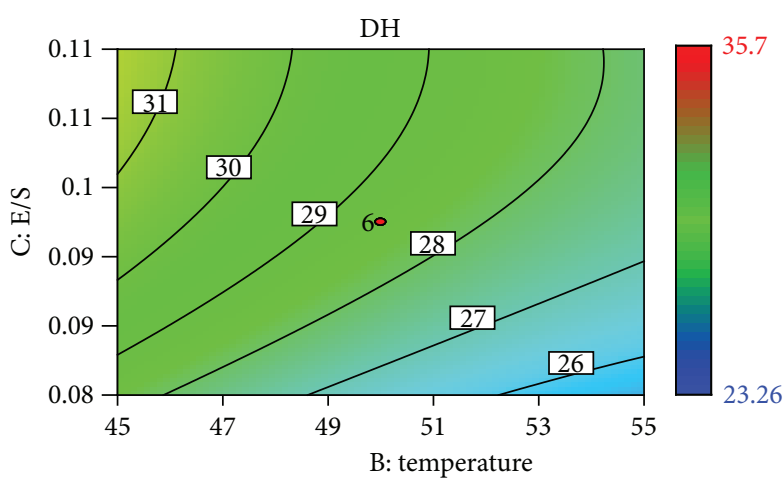

- Design points

(d) Fixed levels: $\mathrm{pH}=7.00$, Incubation period $=10.00 \mathrm{~h}$

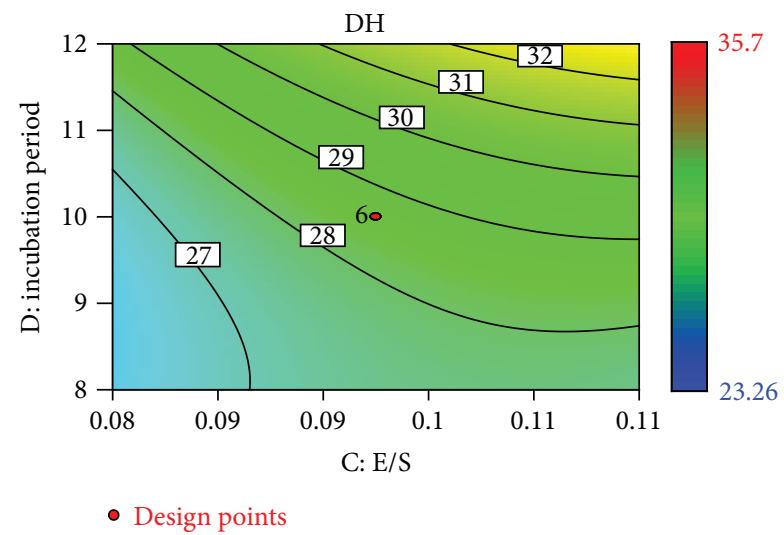

(f) Fixed levels: $\mathrm{pH}=7.00$, Temperature $=50.00^{\circ} \mathrm{C}$

FIGURE 3: Contour plots for the effect of variables on the $\mathrm{DH}$ as a function of various hydrolysis conditions: (a) $\mathrm{pH}$ and temperature, (b) $\mathrm{pH}$ and $\mathrm{E} / \mathrm{S}$, (c) $\mathrm{pH}$ and incubation period, (d) temperature and E/S, (e) temperature and incubation period, (f) E/S and incubation period.

and used to categorize the amino acids as monosodium glutamate-like (MSG-like) (Asp and Glu), sweet (Ala, Gly, Ser, and Thr), bitter (Arg, His, Ile, Leu, Met, Phe, Trp, and Val) and tasteless (Cys, Lys, and Pro). After the enzymatic hydrolysis, the FAA content of the EHBCs had increased 40.46 times over that of the BCs and consisted primarily of bitter amino acids. In contrast, Guo et al. [13] reported that the high mean liberation rates of hydrophobic FAAs upon the enzymatic hydrolysis of porcine blood hemoglobin with admixture possibly decreased the bitterness. The EAA score provides an estimate of the nutritive value of a protein. This parameter compares levels of EAAs between the test and the standard proteins [32]. In the current study, the EAA scores were based on the reference protein of $\mathrm{FAO} / \mathrm{WHO}$ [27] for adults and the amino acid requirements of the pig $(3-10 \mathrm{~kg})$, as listed by the NRC [28]. The amino acid 
composition in this study and its comparison with reference proteins indicated that the EHBCs levels of most of the amino acids including valine, leucine, and histidine were higher in terms of the EAAs, compared with the suggested amino acid pattern recommended by the FAO/WHO [27] for adults; some amino acids, however, were limiting in the EHBCs. Furthermore, the amino acid composition in this study and its comparison with the reference proteins indicated that the amino acids including valine, leucine, histidine, and arginine of the EHBCs were present at higher levels in terms of the EAAs, compared with the suggested amino acid pattern recommended by NRC [28] for pigs (3-10 kg). These results differed from those of Ovissipour et al. [32] because of the $\mathrm{BC}$ substrate's imbalanced amino acid content. The chemical score of the EHBCs showed that isoleucine and the sulfurcontaining amino acids (Met and Cys) were the most limiting amino acids, while the levels of valine, leucine, phenylalanine, tyrosine, histidine and arginine exceeded the requirements for pigs (3-10 kg) [28]. Furthermore, for many animals, including pigs, diets that include large amounts of free amino acids were easily absorbed.

The C-PER values in the current study were 2.04-21.73 for the EHBCs and lower than BCs. However, the results were higher than Yellowfin Tuna and Persian sturgeon [21, 32] due to the abundance of amino acids in the EHBCs. The CPER values indicated the EHBC was a good potential food ingredient for adult humans and pigs (3-10 kg).

\section{Conclusions}

The DH of BCs was studied using single-factor test and the response surface methodology to identify and quantify the variables that optimize the DH. The conditions determined by RSM for the optimal DH included the following parameters: substrate concentration $1.00 \%$, pH 6.50, E/S 0.11, temperature $45.00^{\circ} \mathrm{C}$, and incubation period $12.00 \mathrm{~h}$. Basing on the EHBCs' amino acid compositions and the C-PER, the EHBCs that prepared from the BCs have a high potential for application to adult humans' food and pigs' feeds.

\section{Acknowledgments}

This project is financially supported by the China Agriculture Research System (CARS-36) and the Program for Innovative Research Team of Universities in Heilongjiang Province.

\section{References}

[1] P. K. Mandal, V. K. Rao, B. N. Kowale, and U. K. Pal, "Utilization of slaughter house blood in human food," Journal of Food Science and Technology, vol. 36, no. 2, pp. 91-105, 1999.

[2] D. Parès I Oliva, Caracterizatzió i revaloració de la fracció plasmàtica de la sang de porc procedent d'escorxadors industrials [Ph.D. thesis], Department of Chemical and Agricultural Engineering and Food Technology, University de Girona, 2001.

[3] R. T. Duarte, M. C. Carvalho Simões, and V. C. Sgarbieri, "Bovine blood components: fractionation, composition, and nutritive value," Journal of Agricultural and Food Chemistry, vol. 47, no. 1, pp. 231-236, 1999.
[4] C. Martínez Graciá, G. Lopez Martínez, G. Ros Berruezo, M. L. Vidal Guevara, and P. Abellán Ballesta, "Use of heme iron concentrate in the fortification of weaning foods," Journal of Agricultural and Food Chemistry, vol. 48, no. 7, pp. 2930-2936, 2000.

[5] A. P. Williams, "Amino acid requirements of the veal calf and beef steer," in Amino Acids in Farm Animal Nutrition, J. P. F. D’Mello, Ed., pp. 329-349, CAB International, Oxon, UK, 1994.

[6] E. D. Frugé, S. Powell, T. D. Bidner, and L. L. Southern, "Effect of incremental dietary levels of red blood cells on growth performance of broilers," Journal of Applied Poultry Research, vol. 20, no. 2, pp. 129-135, 2011.

[7] E. Saguer, S. Altarriba, C. Lorca, D. Parés, M. Toldrà, and C. Carretero, "Colour stabilization of spray-dried porcine red blood cells using nicotinic acid and nicotinamide," Food Science and Technology International, vol. 9, no. 4, pp. 301-307, 2003.

[8] M. Toldrà, D. Parés, E. Saguer, and C. Carretero, "Hemoglobin hydrolysates from porcine blood obtained through enzymatic hydrolysis assisted by high hydrostatic pressure processing," Innovative Food Science and Emerging Technologies, vol. 12, no. 4, pp. 435-442, 2011.

[9] R. Pérez-Gálvez, M. C. Almécija, F. J. Espejo, E. M. Guadix, and A. Guadix, "Bi-objective optimisation of the enzymatic hydrolysis of porcine blood protein," Biochemical Engineering Journal, vol. 53, no. 3, pp. 305-310, 2011.

[10] I. Aubes-Dufau, J. L. Seris, and D. Combes, "Production of peptic hemoglobin hydrolysates: bitterness demonstration and characterization," Journal of Agricultural and Food Chemistry, vol. 43, no. 8, pp. 1982-1988, 1995.

[11] J. Synowiecki, R. Jagiełka, and F. Shahidi, "Preparation of hydrolysates from bovine red blood cells and their debittering following plastein reaction," Food Chemistry, vol. 57, no. 3, pp. 435-439, 1996.

[12] H. W. Ockerman and C. L. Hansen, Animal by-Product and Utilization, Technomic Publishing Company, Pennsylvania, $\mathrm{Pa}$, USA, 2000.

[13] S.-G. Guo, M.-M. Zhao, J.-S. Wang, and C. Cui, "Proteolytic degradation and amino acid liberation during extensive hydrolysis of porcine blood hemoglobin by protease admixture," Journal of Food Process Engineering, vol. 30, no. 5, pp. 640-659, 2007.

[14] M. Gaskell and R. Smith, "Nitrogen sources for organic vegetable crops," HortTechnology, vol. 17, no. 4, pp. 431-441, 2007.

[15] M. B. Rust, Quantitative aspects of nutrient assimilation in six species of fish larvae [Ph.D. thesis], Department of Aquatic and Fishery Sciences, University of Washington, 1995.

[16] M. Toldrà, A. Elias, D. Parés, E. Saguer, and C. Carretero, "Functional properties of a spray-dried porcine red blood cell fraction treated by high hydrostatic pressure," Food Chemistry, vol. 88, no. 3, pp. 461-468, 2004.

[17] M. Toldrà, E. Dàvila, E. Saguer et al., "Functional and quality characteristics of the red blood cell fraction from biopreserved porcine blood as influenced by high pressure processing," Meat Science, vol. 80, no. 2, pp. 380-388, 2008.

[18] E. Dàvila Ribot, Advances in animal blood processing: development of a biopreservation system and insights on the functional properties of plasma [Ph.D. thesis], Department of Chemical and Agricultural Engineering and Agrifood Technology, University of Girona, 2006.

[19] G. E. P. Box, W. G. Hunter, and J. S. Hunter, Statistics for Experiments, an Introduction to Design, Data Analysis and 
Model Building, John Wiley and Sons, New York, NY, USA, 1978.

[20] H.-C. Chen, H.-Y. Ju, T.-T. Wu et al., "Continuous production of lipase-catalyzed biodiesel in a packed-bed reactor: optimization and enzyme reuse study," Journal of Biomedicine and Biotechnology, vol. 2011, Article ID 950725, 2011.

[21] M. Ovissipour, A. Abedian Kenari, A. Motamedzadegan, and R. M. Nazari, "Optimization of enzymatic hydrolysis of visceral waste proteins of yellowfin tuna (Thunnus albacares)," Food and Bioprocess Technology, vol. 5, no. 2, pp. 696-705, 2012.

[22] T. Zhu and K. H. Row, "Box-Behnken design for optimizing extraction of luteolin from celery leaves," Journal of Liquid Chromatography and Related Technologies, vol. 34, no. 12, pp. 1036-1049, 2011.

[23] X. Huang, B. Tian, Q. Niu, J. Yang, L. Zhang, and K. Zhang, "An extracellular protease from Brevibacillus laterosporus G4 without parasporal crystals can serve as a pathogenic factor in infection of nematodes," Research in Microbiology, vol. 156, no. 5-6, pp. 719-727, 2005.

[24] X. Li, Z. Niu, and B. Zhang, "Various methods available for the determination of hydrolyzed degree of whey protein," China Dairy Industry, vol. 34, no. 10, pp. 59-62, 2006.

[25] S.-L. Kim, S.-K. Kim, and C.-H. Park, "Introduction and nutritional evaluation of buckwheat sprouts as a new vegetable," Food Research International, vol. 37, no. 4, pp. 319-327, 2004.

[26] AOAC, Official Methods of Analysis, Association of Official Analytical Chemists, Arlington, Va, USA, 7th edition, 2000.

[27] FAO/WHO, "Protein quality evaluation," Report of Joint FAO/WHO Expert Consultation, Food and Agriculture Organization of the United Nations, Rome, Italy, 1991.

[28] NRC, Nutrient Requirements of Swine, National Academy Press, Washington, DC, USA, 10th edition, 1998.

[29] R. H. Alsmeyer, A. E. Cunningham, and M. L. Happich, "Equations predicting PER from amino acid analysis," Food Technology, vol. 28, pp. 34-40, 1974.

[30] Y. B. Lee, J. G. Elliot, D. A. Rickansrud, and E. C. Mugberg, "Predicting protein efficiency ratio by the chemical determinations of connective tissue content in meat," Journal of Food Science, vol. 43, no. 5, pp. 1359-1362, 1978.

[31] R. Šližyte, E. Daukšas, E. Falch, I. Storrø, and T. Rustad, "Characteristics of protein fractions generated from hydrolysed cod (Gadus morhua) by-products," Process Biochemistry, vol. 40, no. 6, pp. 2021-2033, 2005.

[32] M. Ovissipour, A. Abedian, A. Motamedzadegan, B. Rasco, R. Safari, and H. Shahiri, "The effect of enzymatic hydrolysis time and temperature on the properties of protein hydrolysates from Persian sturgeon (Acipenser persicus) viscera," Food Chemistry, vol. 115, no. 1, pp. 238-242, 2009.

[33] Z. Wen, W. Liao, and S. Chen, "Hydrolysis of animal manure lignocellulosics for reducing sugar production," Bioresource Technology, vol. 91, no. 1, pp. 31-39, 2004.

[34] M. Chen, L. Xia, and P. Xue, "Enzymatic hydrolysis of corncob and ethanol production from cellulosic hydrolysate," International Biodeterioration and Biodegradation, vol. 59, no. 2, pp. 85-89, 2007.

[35] N. J. Cao, M. S. Krishnan, J. X. Du et al., "Ethanol production from corn cob pretreated by the ammonia steeping process using genetically engineered yeast," Biotechnology Letters, vol. 18, no. 9, pp. 1013-1018, 1996.

[36] I. Batista, C. Ramos, J. Coutinho, N. M. Bandarra, and M. L. Nunes, "Characterization of protein hydrolysates and lipids obtained from black scabbardfish (Aphanopus carbo) byproducts and antioxidative activity of the hydrolysates produced," Process Biochemistry, vol. 45, no. 1, pp. 18-24, 2010.

[37] C. Hu, J. Cui, F. Ren, and C. Peng, "Enzyme hydrolysis of silk fibroin and the anti-diabetic activity of the hydrolysates," International Journal of Food Engineering, vol. 4, no. 2, article 13, 2008.

[38] W. D. Wang and S. Y. Xu, "Degradation kinetics of anthocyanins in blackberry juice and concentrate," Journal of Food Engineering, vol. 82, no. 3, pp. 271-275, 2007.

[39] F. Guerard, L. Guimas, and A. Binet, "Production of tuna waste hydrolysates by a commercial neutral protease preparation," Journal of Molecular Catalysis B, vol. 19-20, pp. 489-498, 2002.

[40] M. Ovissipour, R. Safari, A. Motamedzadegan, and B. Shabanpour, "Chemical and biochemical hydrolysis of persian sturgeon (Acipenser persicus) visceral protein," Food and Bioprocess Technology, vol. 5, no. 2, pp. 460-465, 2012.

[41] P. K. Sarkar, L. J. Jones, G. S. Craven, S. M. Somerset, and C. Palmer, "Amino acid profiles of kinema, a soybean-fermented food," Food Chemistry, vol. 59, no. 1, pp. 69-75, 1997.

[42] Y. H. Tseng, Y. L. Lee, R. C. Li, and J. L. Mau, "Non-volatile flavour components of Ganoderma tsugae," Food Chemistry, vol. 90, no. 3, pp. 409-415, 2005. 

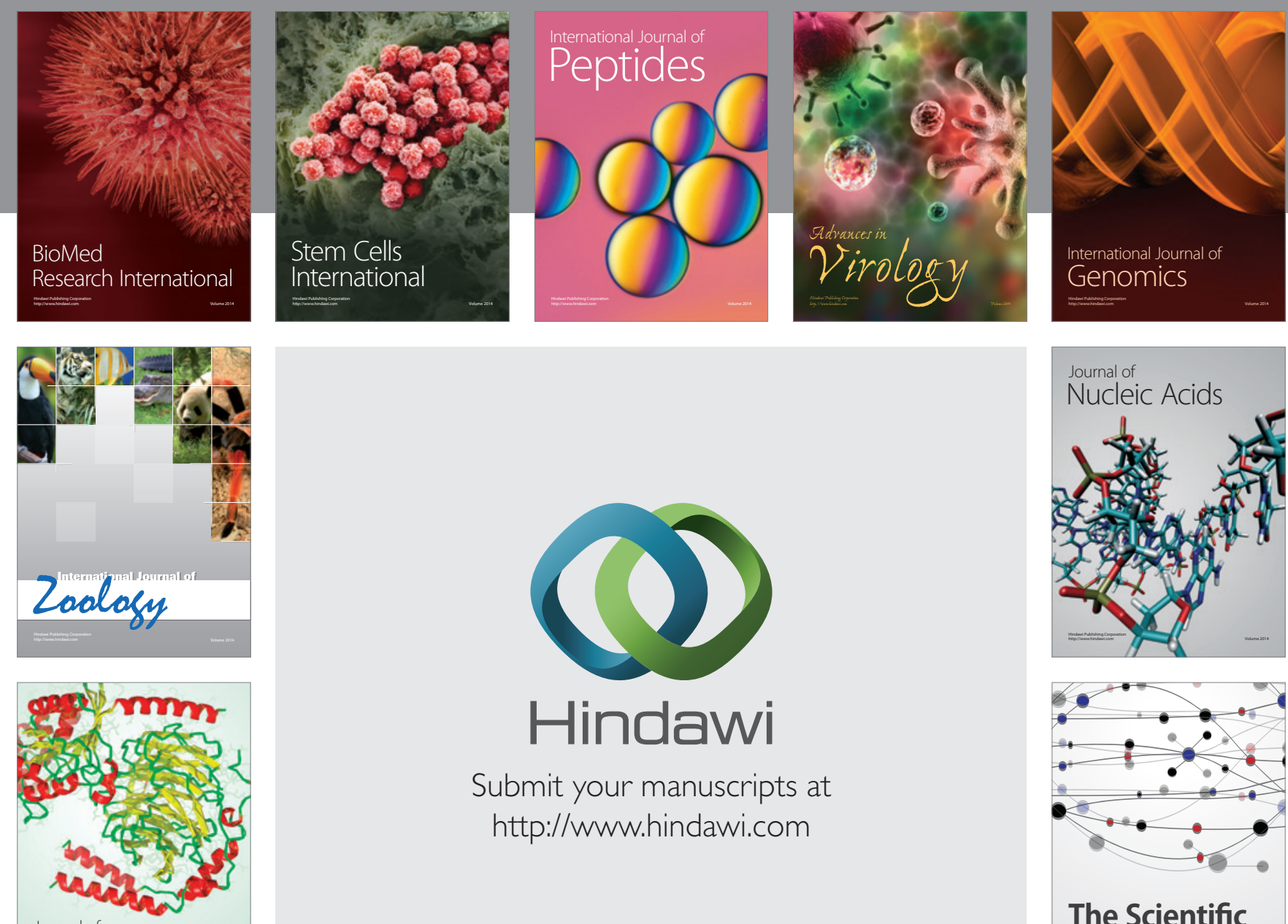

Submit your manuscripts at

http://www.hindawi.com

Journal of
Signal Transduction


The Scientific World Journal
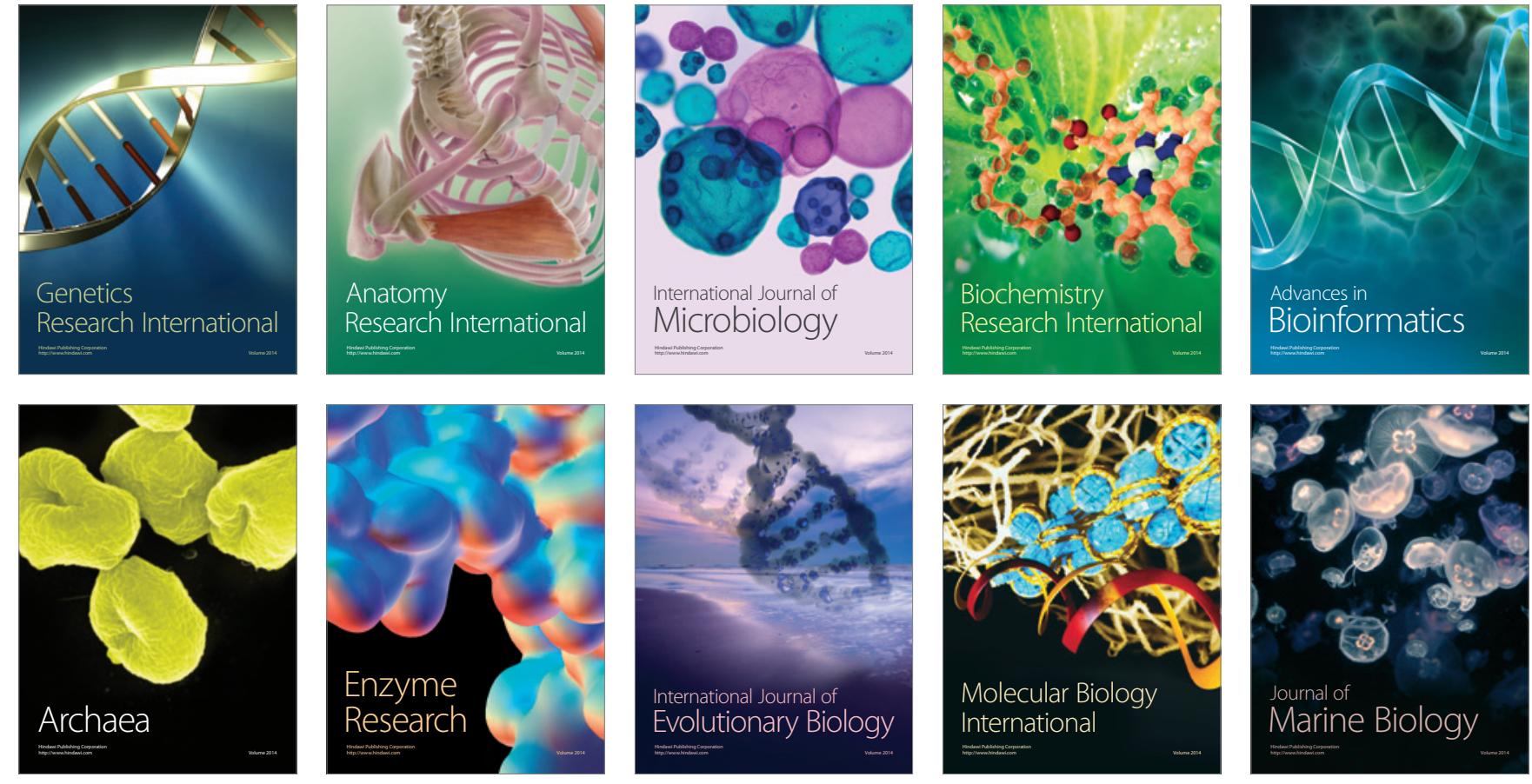